\title{
Population Dynamics of Shoot and Fruit Borer Earias vitella of Okra, Abelmoschus esculentus (L.) Moench during Kharif 2016
}

\author{
V.N. Parijatha ${ }^{1 *}$, Sasya Thakur ${ }^{1}$ and B.P. Chandrappa ${ }^{2}$ \\ ${ }^{1}$ Department of entomology, SHUATS Allahabad-211 007, Uttar Pradesh, India \\ ${ }^{2}$ Department of plant pathology, GKVK, UAS Bengalore-560065, Karnataka, India \\ *Corresponding author
}

\section{A B S T R A C T}

Keywords

Earias vittella, Population dynamics, Shoot and fruit borer

Article Info

Accepted:

10 August 2018

Available Online:

10 September 2018
The present investigation entitles "Population dynamics shoot and fruit borer Earias vitella of okra, Abelmoschus esculentus (L.) Moench during kharif 2016." cultivar komal conducted during August, to November, 2016 at field of Entomology SHUATS Allahabad. The occurrence of shoot and fruit borer (Earias vittella) in 2016 kharif season was commenced from $36^{\text {th }}$ standard week with an average $2.758 \%$ infestation. The shoot and fruit borer population increased and gradually reached peak level of $43.917 \%$ infestation at $43^{\text {rd }}$ standard week. It was found that population of shoot and fruit borer increased with increasing maximum temperature and positively correlated with maximum temperature.

\section{Introduction}

Okra Abelmoschus esculentus (L.) Moench, a native of South-Africa and commonly known as 'Bhindi', is an annual malvaceous vegetable crop, especially grown in tropical and subtropical climates. Its tender green fruits are very nutritious.

Among, several biotic and abiotic factors, the incidence of insect pests are one of the major factors reducing the yield of okra. Twenty different insect species are known to attack okra, inflicting qualitative and quantitative production losses (Butani and Verma, 1976). Nayar et al., (1976) reported more than three dozen insect pests are attacking okra. Out of numerous insect pests shoot and fruit borer,
Earias vittella (Fab.) is one of the major insect pest. The Moth is yellow green and measures about $2.5 \mathrm{~cm}$ across the wings. It is having a narrow light longitudinal green band in the middle of forewing. The full grown caterpillars are dull-green in colour and are $2 \mathrm{~cm}$ long having tiny stout bristles and a series of longitudinal black spots on the body

The female moth lays 200-400 eggs at night singly on flower buds, bracts and tender leaves of Okra plants. Incubation period of eggs are 3-4 days and caterpillar pass through 6 stages, becoming full grown in 10-16 days. They pupate either on plants or on ground among fallen leaves and the moth emerge in 8-14 days in summer and 18-23 days in winter. Lifecycle is completed in 17-29 days. 
Okra is grown during summer and kharif seasons. Among insect pests infesting okra, shoot and fruit borer Earias vittella (Fabricius) is one of the serious pests causing 40-50 per cent damage to okra fruits during both season (Srinivashan and Gowder, 1960). Earias Spp. alone causes damage ranging from 52.33 to 70.75 percent (Pareek and Bhargava, 2009). In India, okra occupies an area of 4.09 lac ha with production of 41.92 lac MT/ ha and productivity of $10.3 \mathrm{MT} / \mathrm{ha}$ (Shri Bijay Kumar, 2008)

\section{Materials and Methods}

The experiment was taken out in Allahabad region was carried out during July 2016 to November 2016 at Agricultural Research Farm of Sam Higginbottom University of Agriculture, Technology and Sciences, Allahabad, Uttar Pradesh, India. The okra variety Komal was sown @ 8 kg/ha by dibbling method with spacing of $45 \mathrm{~cm}$ between row to row and $30 \mathrm{~cm}$ between plant to plant by placing 2-3 seeds per hill at depth of $4 \mathrm{~cm}$. Sowing was done on 10/08/2016. All the recommended agronomic practices (irrigation, fertilizer etc.) were strictly followed.
To assess the incidence of shoot and fruit borer (Earias vitella), the number of larvae per plant were counted and recorded at weekly intervals on 25 randomly selected plants. The population dynamics was determined by correlating weather parameter and sucking pests and shoot and fruit borer (Earias vitella).

The data so obtained through observation on various apects were subjected to statistical analysis and the compiled mean data have been tabulated.

\section{Results and Discussion}

Studies on the population dynamics of shoot and fruit borer population with weather parameters given in table 1 . The results showed that earliest occurrence of shoot and fruit borer (Earias vittella) in 2016 rainy season was commenced from $36^{\text {th }}$ standard week with an average $2.758 \%$ infestation. The shoot and fruit borer population increased and gradually reached peak level of $43.917 \%$ infestation at $43^{\text {rd }}$ standard week (Table 1). Thereafter, declined trend was observed due to fall of maximum and minimum temperatures as optimum weather condition are decreasing (Fig. 1).

Fig.1 Population dynamics of shoot and fruit borer [Earias vittella (Fabricus)] of okra during kharif 2016

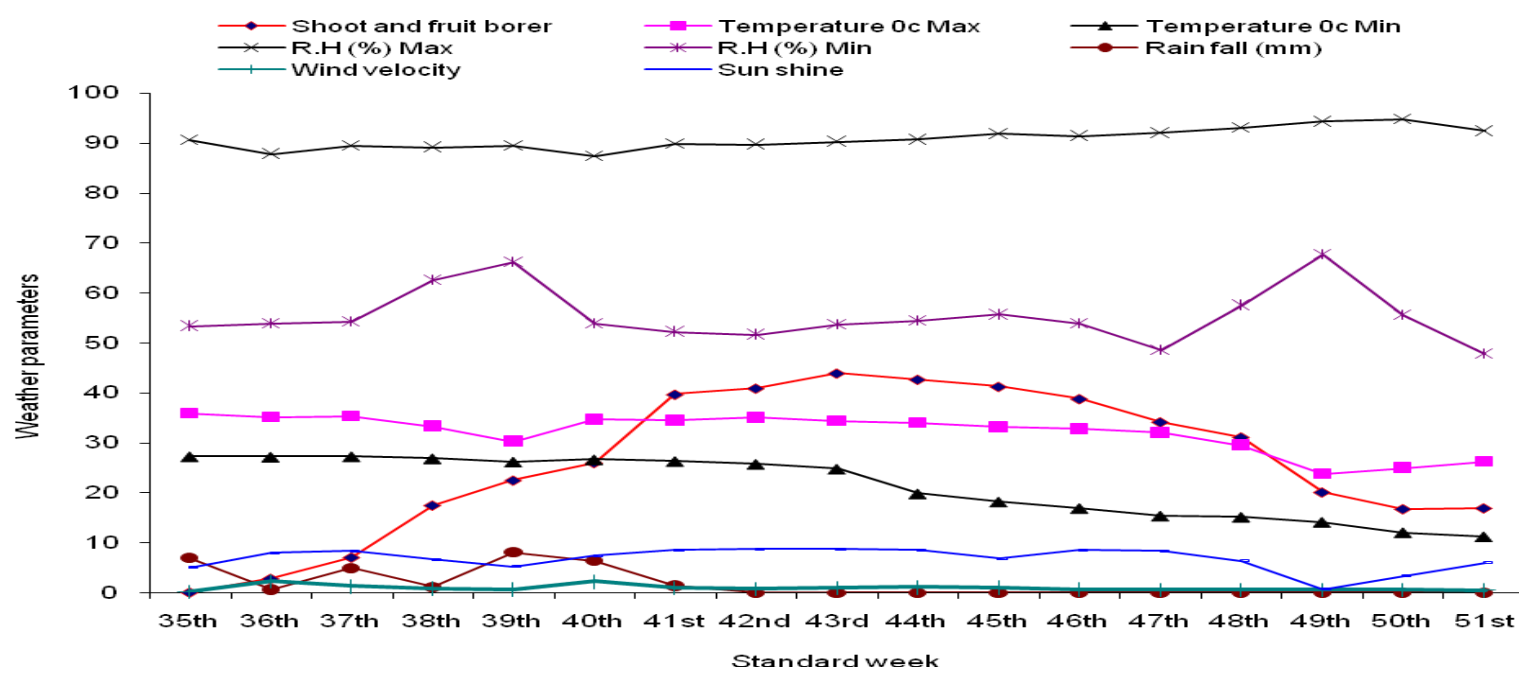


Table.1 Population dynamics of shoot and fruit borer [Earias vittella (Fabricus)] of okra during kharif 2016

\begin{tabular}{|c|c|c|c|c|c|c|c|c|}
\hline $\begin{array}{c}\text { Standard } \\
\text { week }\end{array}$ & $\begin{array}{c}\text { Shoot and } \\
\text { fruit borer }\end{array}$ & \multicolumn{2}{|c|}{ Temperature } & \multicolumn{2}{|c|}{ Humidity } & Rainfall & $\begin{array}{c}\text { Wind } \\
\text { Velocity }\end{array}$ & $\begin{array}{c}\text { Sunshine } \\
\text { (hr/day) }\end{array}$ \\
\hline $\mathbf{3 5}^{\text {th }}$ & 0 & 35.82 & 27.28 & 90.57 & 53.42 & 6.94 & 0.25 & 5.07 \\
\hline $\mathbf{3 6}^{\text {th }}$ & 2.758 & 35.14 & 27.2 & 87.85 & 53.85 & 0.65 & 2.26 & 8.08 \\
\hline $\mathbf{3 7}^{\text {th }}$ & 7.019 & 35.25 & 27.28 & 89.42 & 54.28 & 4.91 & 1.26 & 8.34 \\
\hline $\mathbf{3 8}^{\text {th }}$ & 17.456 & 33.28 & 26.87 & 89.14 & 62.57 & 1.14 & 0.87 & 6.62 \\
\hline $\mathbf{3 9}^{\text {th }}$ & 22.456 & 30.25 & 26.22 & 89.42 & 66.28 & 8.08 & 0.66 & 5.28 \\
\hline $\mathbf{4 0}^{\text {th }}$ & 25.971 & 34.65 & 26.68 & 87.42 & 53.85 & 6.37 & 2.22 & 7.45 \\
\hline $\mathbf{4 1}^{\text {st }}$ & 39.67 & 34.48 & 26.34 & 89.85 & 52.28 & 1.42 & 1.01 & 8.52 \\
\hline $\mathbf{4 2}^{\text {nd }}$ & 40.892 & 35.05 & 25.77 & 89.71 & 51.71 & 0 & 0.81 & 8.77 \\
\hline $\mathbf{4 3}^{\text {rd }}$ & 43.917 & 34.37 & 24.8 & 90.28 & 53.71 & 0 & 1.01 & 8.75 \\
\hline $\mathbf{4 4}^{\text {th }}$ & 42.671 & 33.97 & 19.82 & 90.71 & 54.42 & 0 & 1.08 & 8.57 \\
\hline $\mathbf{4 5}^{\text {th }}$ & 41.24 & 33.14 & 18.2 & 91.85 & 55.71 & 0 & 1.02 & 6.91 \\
\hline $\mathbf{4 6}^{\text {th }}$ & 38.786 & 32.74 & 16.91 & 91.42 & 53.85 & 0 & 0.66 & 8.51 \\
\hline $\mathbf{4 7}^{\text {th }}$ & 34.141 & 31.97 & 15.37 & 92 & 48.57 & 0 & 0.61 & 8.42 \\
\hline $\mathbf{4 8}^{\text {th }}$ & 31.107 & 29.51 & 15.15 & 93.03 & 57.58 & 0 & 0.56 & 6.37 \\
\hline $\mathbf{4 9}^{\text {th }}$ & 20.079 & 23.8 & 14.14 & 94.28 & 67.71 & 0 & 0.57 & 0.68 \\
\hline $\mathbf{5 0}^{\text {th }}$ & 16.718 & 24.97 & 12.05 & 94.71 & 55.57 & 0 & 0.60 & 3.34 \\
\hline $\mathbf{5 1}^{\text {st }}$ & 16.891 & 26.2 & 11.22 & 92.42 & 47.85 & 0 & 0.52 & 6.02 \\
\hline & $\mathbf{R}$ & $\mathbf{0 . 1 1 0}$ & $\mathbf{- 0 . 1 8 5}$ & $\mathbf{0 . 1 1 2}$ & $\mathbf{- 0 . 1 6 0}$ & $\mathbf{- 0 . 4 6 4}$ & $\mathbf{- 0 . 0 9 8}$ & $\mathbf{0 . 4 2 6}$ \\
\hline & $\mathbf{t =}$ & $\mathbf{0 . 4 2 7}$ & $\mathbf{- 0 . 7 2 9}$ & $\mathbf{0 . 4 3 8}$ & $\mathbf{- 0 . 6 2 6}$ & $\mathbf{- 2 . 0 2 9}$ & $\mathbf{- 0 . 3 8 0}$ & $\mathbf{1 . 8 2 6}$ \\
\hline & $\mathbf{R e s u l t s}$ & $\mathbf{S}$ & $\mathbf{S}$ & $\mathbf{S}$ & $\mathbf{S}$ & $\mathbf{N S}$ & $\mathbf{S}$ & $\mathbf{S}$ \\
\hline & & & & & \\
\hline
\end{tabular}

These observations are in close agreement with Nenavati and Kumar (2014) studied that occurrence of shoot and fruit borer commenced from 33rd standard week (August third week) with an average population of infestation $2.4 \%$ and gradually reached its peak level of infestation $45.7 \%$ at $41 \mathrm{st}$ standard week (October second week) thereafter declined trend was observed as temperature decreased. Sharma et al., (2010) reported that correlation between pest population and important weather parameters showed that Earias population was negatively correlated with the mean temperature and mean relative humidity but non-significantly and negatively correlated with rainfall in terms of larval population and percentage of infested plants. Prasad et al., (2011) reported that the maximum damage $43.52 \%$ and
$42.31 \%$ in $41 \mathrm{st}$ and $33^{\text {rd }}$ standard weeks respectively during both the years were caused by Earias vittella. The temperature with per cent fruit damage showed significant negative relationship during 2005 and 2006 and RH showed no significant positive relationship with this pest. Bishara (1968) reported the fruit borer infestation to peak during October and November on cotton.

\section{References}

Bishara, I. (1968) Bollworm attack in relation to manuring of cotton. Tech. Bull. UAR, Minst. Agric. No.1: 35.

Butani, D.K. and Verma, S. (1976). Insect pests of vegetables and their controlLady's finger. Pesticides; 10 (7): 31-70. 
Nayar K. K., Annthakrishnan, T. N. and David, B. V. (1976).General and Applied Entomology. Tata Mc. Graw Hill Publ. Co. Ltd., New Delhi, 489p.

Nenavati, R. N. and Kumar, A. (2014). Efficacy of certain insecticides and seasonal incidence of shoot and fruit borer, Earias vittella Fab. Annals of Plant Protection Sciences, 22(1): 95-97

Pareek, B.L. and Bhargava, M.C. (2009.) Estimation of avoidable losses in vegetable crops caused by borers under semi-arid conditions of Rajasthan. Insect Environment; 9: 59-60.

Prasad, L. C. S., Tiwari, G. N. and Kumar, A. (2011). Impact of weather parameters on major insect pests of okra prevailing western Uttar Pradesh. Vegetos, 24(2): $152-156$.

Sharma, R.P., Swaminathan, R. and Bhati, K.K. (2010). Seasonal incidence of fruit and shoot borer of okra along with climatic factors in Udaipur region of India; Asian journal of agriculture research 4(4); 232-236.

Shri Bijay Kumar, (2008) Indian horticulture data base. pp. -185 .

Srinivasan, P.M. and Gowder, R.B. (1960). Preliminary notes on the control of bhendi shoot and fruit borer, Earias fabia and Earias insulana. Indian $J$. Agric. Sci.30 (1): 55-57.

\section{How to cite this article:}

Parijatha, V.N., Sasya Thakur and Chandrappa, B.P. 2018. Population Dynamics of Shoot and Fruit Borer Earias vitella of Okra, Abelmoschus esculentus (L.) Moench during Kharif 2016. Int.J.Curr.Microbiol.App.Sci. 7(09): 1358-1361. doi: https://doi.org/10.20546/ijcmas.2018.709.162 